\title{
PELATIHAN KETERAMPILAN MODEL ANYAMAN DARI KERTAS ASTURO SEBAGAI MEDIA PEMBELAJARAN SENI BUDAYA DAN PRAKARYA BAGI GURU SEKOLAH DASAR
}

\author{
Sumanto*, A.Taufiq, Murtiningsih \\ Jurusan KSDP, Fakultas Ilmu Pendidikan, Universitas Negeri Malang, Indonesia \\ Jalan Semarang No. 5 Malang, Jawa Timur, Indonesia \\ *e-mail: sumantomunginan@gmail.com
}

artikel masuk: 6 Desember 2019; artikel diterima: 6 April 2020

\begin{abstract}
Training in making woven models as a medium for learning art and culture and this workshop aims to train skills: making woven models from asturo paper to improve the quality of visual art learning in elementary schools. Training methods by providing individual practice guidance to weaving skills directly to 20 elementary school teachers. The results of this community service activity are (1) non-physical for elementary school teachers in cluster 3 Donowarih Karangploso are very interested in getting art training and are willing to disseminate knowledge and skills to other teachers in their assignments. (2) individual trainees are skilled in making woven shapes of fish, flying birds, stars, baskets, and ribbon-shaped woven frames.
\end{abstract}

Keywords: Skills; woven models; paper; elementary school teachers

\begin{abstract}
Abstrak: Pelatihan pembuatan model karya anyaman sebagai media pembelajaran seni budaya dan prakarya ini bertujuan melatih keterampilan: membuat model-model anyaman dari kertas asturo untuk meningkatkan kualitas pembelajaran senirupa di SD. Metode pelatihan dengan memberikan bimbingan praktek individu keterampilan menganyam secara langsung kepada 20 guru SD. Hasil dari kegiatan pengabdian ini adalah (1) non-fisik bagi guru-guru SD di gugus 3 Donowarih Karangploso sangat berminat mendapat pelatihan senirupa-prakarya, dan bersedia untuk menyebarluaskan pengetahuan dan keterampilan kepada guru lain di tempat tugasnya. (2) peserta pelatihan secara individu terampil membuat anyaman bentuk ikan, burung terbang, bintang, keranjang (besek), dan anyaman pita bentuk pigura.
\end{abstract}

Kata kunci: Keterampilan; model anyaman; kertas; guru SD

\section{PENDAHULUAN}

Salah satu gugus sekolah yang ada di kecamatan Karangploso adalah Gugus 3 Donowarih yang mencakup 6 lembaga satuan pendidikan Sekolah Dasar, yaitu SDN Donowarih 1, SDN 
Donowarih 2, SDN Tawangargo 1, SDN Tawangargo 2, SDN Tawangargo 3, SDN Bocek, dan SDN Ngenep. Dilihat dari acuan kurikulum yang digunakan dalam pembelajaran di kelas semuanya sudah melaksanakan Kurikulum 2013. Guru kelas SD sebagai tenaga pendidik profesional yang berperan sebagai fasilitator dalam pembelajaran dituntut kreativitasnya untuk menggali potensi sumber belajar, materi pembelajaran, dan media pembelajaran yang ada di lingkungannya agar dapat membelajarkan muridnya secara berkualitas. Agar dapat jadi fasilitator yang baik guru SD diharapkan dapat membekali diri dengan wawasan dan keterampilan kreatif mengembangkan materi pembelajaran yang berorientasi pada aktivitas kreatif anak. Salah satu muatan materi pelajaran yang sarat akan kemampuan kreatif guru kelas adalah pembelajaran Seni Budaya dan Prakarya (SDdP). Sesuai dengan kompetensi dasar dan indikator yang ada pada muatan SBdP aspek keterampilan (KI4) berkaitan dengan materi praktek berkarya kreatif senirupa. Diantaranya Menggambar, Mencetak, Membentuk, Aplikasi mosaik, montase, kolase, jenis-jenis berkarya Prakarya (kerajinan tangan) dan lainnya.

Secara umum fenomena yang ada di lapangan (di kelas) para guru merasa kurang memiliki kemampuan terampil kreatif untuk membelajarkan kemampuan berkarya kreatif pada siswa di kelasnya. Kondisi yang demikian disebabkan para guru kurang memahami dan kurang terampil dalam mempraktekkan beragam karya senirupa. Seharusnya ada kemampuan kreatif dari para guru kelas, namun kenyataannya belum dimiliki keterampilan tersebut. Dampak yang dilihat di kelas yaitu pembelajaran SBdP masih kurang berjalan dengan baik. Dalam konteks ini guru sebagai fasilitator masih diperlukan atau dibutuhkan bekal pengetahuan dan keterampilan membelajarkan senirupa dengan lebih kreatif agar dapat menjalankan perannya dengan baik, dengan ditunjang ketersediaan media pembelajaran sesuai materi serta tujuan pembelajarannya. Tanpa bekal yang cukup guru SD tidak akan dapat meningkatkan kwalitas pembelajaran SBdP dalam melaksanakan tugasnya.

Dari hasil observasi awal dan wawancara singkat dengan beberapa guru dan kepala SD serta pengurus gugus 3 Donowarih yang ada di wilayah kecamatan Karangploso menunjukkan bahwa para guru SD pada umumnya mengalami kesulitan dalam meningkatkan kwalitas pembelajaran SBdP di SD nya masing-masing. Keadaan ini disebabkan kurangnya sarana dan prasarana berupa contoh-contoh model karya senirupa yang dapat dimanfaatkan sebagai media pembelajaran. Contoh model karya senirupa sebagai media pembelajaran yang sesuai atau tepat berkaitan dengan capaian kompetensi keterampilan kreatif pada kompetensi dasar dan indikatornya. Melalui model karya senirupa tersebut diyakini dapat memotivasi kerja kreatif siswa dengan memanfaatkan potensi bahan alam dan buatan yang ada dilingkungan sekitar.

Berdasarkan hasil kegiatan Abdimas (Sumanto \& Sukamti. 2018) baik yang bersifat fisik maupun non fisik yang berupa adanya perubahan kondisi pengetahuan, keterampilan bagi peserta pelatihan, maka dapat disimpulkan sebagai berikut. Pertama, pelatihan senirupa-prakarya bagi guru-guru SD di Kecamatan Karangploso yang berupa pelatihan keterampilan mencetak tinggi, menganyam untuk meningkatkan kualitas pembelajaran senirupa di SD telah berhasil dengan baik. Kedua, secara khusus, keberhasilan kegiatan ini meliputi: (a) guru SD peserta pelatihan telah dapat menjelaskan konsep pengembangan materi berkarya kreatif senirupa khususnya menganyam bahan kertas asturo dan mencetak tinggi bahan kardus, sterefoam, serta limbah kemasan alat tulis. (b) guru SD peserta pelatihan telah terampil melakukan teknik mencetak tinggi, dan menganyam sesuai bahan yang digunakan dan kreasi yang dibuat, (c) guru SD peserta pelatihan telah mampu membuat karya anyaman bentuk pesawat, ikan, pigura, burung terbang, bintang, dan kotak/besek. (d) guru SD peserta pelatihan telah mampu membuat karya seni cetak tinggi dari acuan sterefoam, acuan potongan kardus, dan acuan limbah kemasan alat tulis dan lainnya. Berdasarkan kesimpulan 
di atas disarankan perlu adanya pelatihan seni keterampilan SD bagi guru-guru berupa pembuatan contoh-contoh karya senirupa dari bahan alam dan buatan yang dapat dimanfaatkan sebagai media pembelajaran, khususnya untuk muatan matapelajaran SBdP.

Berdasarkan analisis kebutuhan kelompok sasaran dan hasil Abdimas tahun 2018 tersebut maka diusulkan kegiatan pengabdian kepada masyarakat tentang "Pelatihan Pembuatan Model Karya Senirupa Sebagai Media Pembelajaran Seni Budaya dan Prakarya Bagi Guru-guru SD di Kecamatan Karangploso Kabupaten Malang". Model karya senirupa yang direncakan akan dilatihkan secara teknologi memiliki kebaruan (novelty) pada sisi pengolahan bahan dan kreasi karya yang dihasilkan. Contoh: (1) pada model karya senirupa dwimatra dengan memilih bahan kertas Asturo dapat dibuat model anyaman dasar dengan potongan kertas lengkung, bergelombang dan patah-patah. (2) pada model karya senirupa trimatra dengan memlih bahan limbah kertas, plastik dapat dibuat model konstruksi, dan merangkai. Kecermatan dalam mengolahan bahan (material) senirupa untuk dikreasi menjadi model karya visual yang bernilai estetis sebagai media pembelajaran. Secara spesifik pelatihan pembuatan model karya senirupa yang direncanakan adalah (a) membentuk model karya seni patung teknik konstruksi dari bahan alam dan buatan, (b) melukis aplikasi dari bahan alam dan buatan, (c) kerajinan anyaman, (d) mencetak sablon sederhana, dan (e) merangkai dari bahan buatan.

Dampak dari keadaan ini akan meningkatkan produktifitas dan kwalitas pembelajaran di SD yang pada akhirnya akan tercapainya tujuan pendidikan di daerah sasaran. Dasar pertimbangan dipilihnya lokasi daerah sasaran stategis ini dikarenakan masih membutuhkan tindak lanjut pembinaan/pelatihan bagi guru kelas dalam bidang muatan mata pelajaran SBdP.

\section{METODE}

Tahap kegiatan yang dilakukan Satgas adalah sebagai berikut. (1) mempelajari terlebih dahulu tentang teknik berkarya kreatif senirupa di SD, Acuannya berkaitan dengan kompetensi dasar dan indikator materi mencetak, dan menganyam. (2) memperkaya tentang pengetahuan keragaman teknik berkarya kreatif senirupa keterampilan melalui observasi media, alat dan proses pembuatan dari setiap karya senirupa yang akan dilatihkan. (3) observasi di lingkungan masyarakat sasaran untuk mengidentifikasi berbagai bahan buatan yang sesuai dengan pembuatan karya kreatif senirupa dan pembelajaran serta contoh karya senirupa yang paling efektif dan efisien. (4) membuat prototype model contoh karya senirupa keterampilan yang representatif dan memenuhi syarat keindahan dan kepraktisan dalam proses pembuatnnya. (5) khalayak sasaran diberi pelatihan pembuatan karya senirupa keterampilan sesuai dengan jadwal yang sudah disepakati. (6) Peserta pelatihan dengan bimbingan satgas mempraktekkan membuat karya anyaman model ikan, pita, bintang, burung terbang, keranjang/besek, serta dompet. Hasil pelatihan berupa produk model karya anyaman, karya seni cetak ini dijadikan bahan evaluasi terhadap keberhasilan peningkatan kemampuan guru-guru SD sebagai kelompok sasaran.

Metode pelatihan yang digunakan meliputi ceramah Tanya jawab, demontrasi, praktek membuat karya senirupa keterampilan serta kerja individu. Secara lebih rinci metode pelatihan dijelaskan berikut ini. Ceramah dan Tanya jawab untuk menyampaikan materi pengembangan senirupa dan berkarya kreatif senirupa, Demonstrasi untuk memperagakan tahap-tahap membuat model anyaman dan karya cetak, pemberian bimbingan praktek berkarya anyaman secara individual dengan memanfaatkan bahan yang telah disediakan.

\section{HASIL DAN PEMBAHASAN}

Pelaksanaan pelatihan keterampilan membuat anyaman ini merupakan bagian dari Abdimas pelatihan SBdP yang dilaksanakan tanggal 21 dan 22 September 2019, dengan kelompok sasaran 
20 guru SD di gugus 1 Kecamatan Ngantang Kabupaten Malang. Dari pelatihan tersebut telah dicapai dua hasil, yaitu hasil non-fisik dan hasil fisik berupa produk karya senirupa.

\section{Hasil Pelatihan Non Fisik}

Satgas menberikan paparan materi berkarya kreatif senirupa dwimatra dan trimatra dengan memanfaatkan ketersediaan LCD ada di ruang kelas tempat pelatihan. Secara teknik satgas juga dibantu oleh alumni PGSD UM yang sekarang sudah mengajar di SDN gugus 3 Donowarih Karangoloso Malang. Kemudian diteruskan dengan penjelasan dan peragaan cara membuat modelmodel karya kerajinan anyaman dari bahan kertas asturo

Pelatihan yang pertama yaitu membuat kreasi anyaman model Ikan dari kertas Asturo. Pada saat peserta pelatihan diberikan praktek berkarya kerajinan anyaman model Ikan tersebut, terlebih dahulu diberikan peragaan langkah-langkah menganyam oleh Satgas Abdimas.

Dengan menggunakan kertas Asturo ukuran lebar $5 \mathrm{~cm}$ dan panjang $35 \mathrm{~cm}$ yang telah dipersiapkan oleh satgas, terlihat aktifitas para peserta secara individu dengan sangat aktif membuat anyaman model ikan (Gambar 1). Selama proses menganyam masih terlihat adanya kesulitan menganyam dengan cermat, rapi dari beberapa peserta, sehingga masih diperlukan bimbingan secara individu.

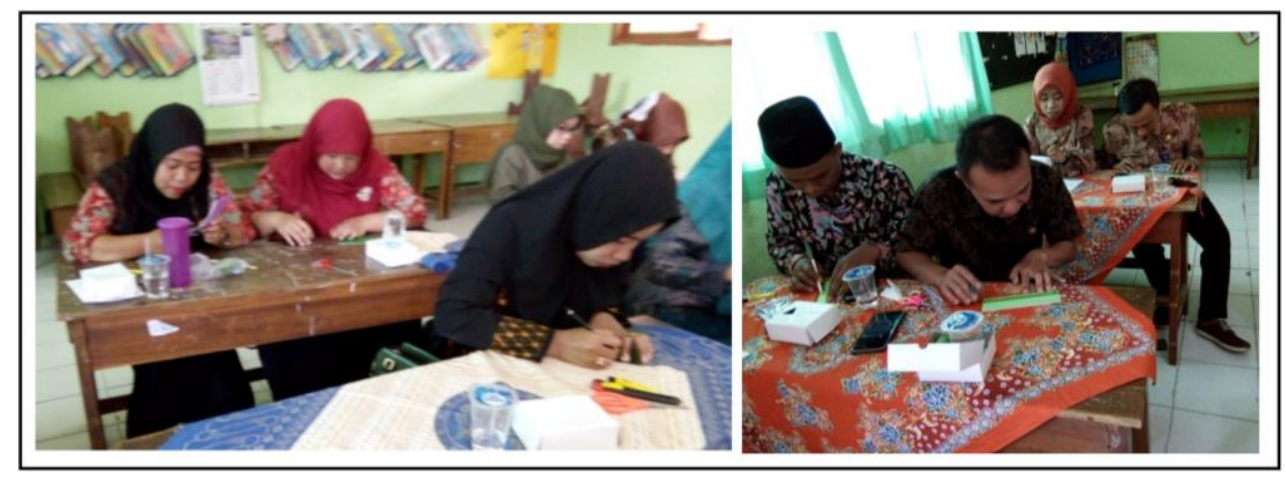

\section{Gambar 1. Peserta sedang mengukur dan mengunting kertas Asturo yang akan dibuat anyaman Model Ikan}

Tahapan kerja membuat anyaman model Ikan yang dilakukan peserta yaitu: (1) mengukur dan menggunting lembaran kertas menjadi beberapa potongan berukuran $0.5 \mathrm{~cm}$. (2) mulai melipat terus dibertuk anayaman sampai dihasilkan model ikan, (3) merapikan, merapatkan bagian-bagian anyaman diakhiri dengan mengunci hasil anyaman kertas dengan cara menyusufkan beberapa ujung kelebihan potongan kertas baik ke bagian luar (atas) dan kebagian dalam (bawah).

Praktek kerajinan anyaman yang kedua, yaitu membuat anyaman Pita yang dibentuk Pigura. Pada latihan yang kedua ini juga diberikan peragaan dan bimbingan seara klasikal dan individu pada tahapan melipat dan menganyam pita kertas asturo untuk dibentuk pigura (Gambar 2). Hasil anyaman pigura akan digunakan untuk menempelkan karya anyaman model ikan yang telah dibuat sebelumnya.

Selama proses membuat anyaman model pita membutuhkan waktu yang lebih lama. Tingkat kesulitan yang terlihat pada peserta pelatihan yaitu pada tahapan membuat anyaman membentuk sudut-sudut dibagian kanan dan kiri, serta pada lipatan (anyaman) di belokan (tikungan) agar bisa membentuk bidang pigura Selanjutnya dari hasil membuat model anyaman pita akan disusun dan ditempelkan pada dasaran karton untuk dibentuk Pigura (Gambar 3).

Setelah pembuatan model pigura dilanjutkan dengan penjelasan dan peragaan oleh satgas mengenai cara menyusun atau menempelkan model ikan pada karton yang pinggirnya telah 
dibentuk pigura anyaman pita. Satgas memberikan petunjuk menyusun/menempelkan hasil anyaman model Ikan pada Pigura.

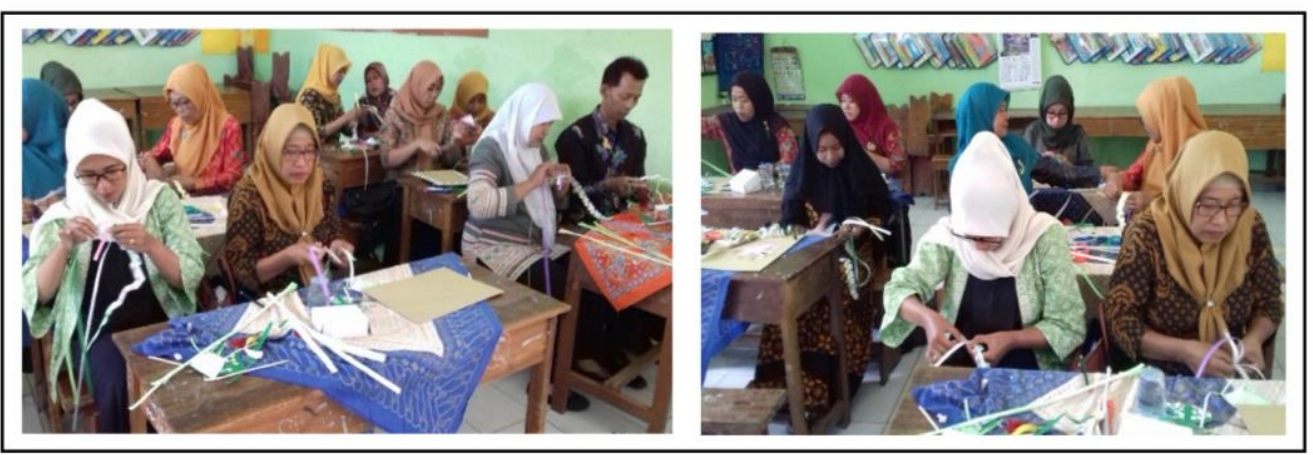

Gambar 2. Peserta secara individu berlatih membuat model anyaman Pita

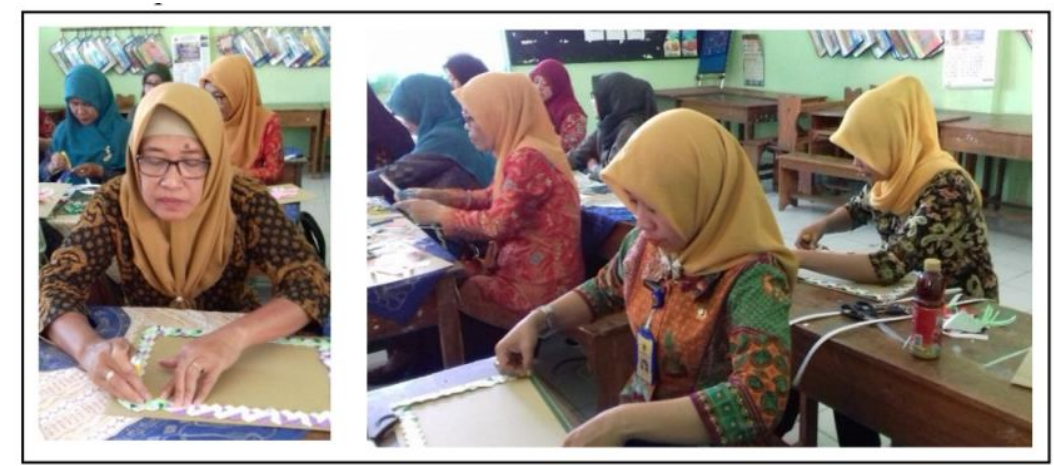

\section{Gambar 3. Peserta menempelkan hasil anyaman pita menjadi model Pigura}

Praktek anyaman keempat, yaitu model Burung Terbang. Setelah diberikan penjelasan dan peragaan membuat anyaman bentuk Burung Terbang selanjutnya setiap peserta mulai mempraktekkannya, dengan menggunakan kertas Asturo yang sudah dipersiapkan. Praktek anyaman kelima, yaitu Bentuk Bintang. Dengan menggunakan empat potong kertas Asturo, ukuran lebar $2 \mathrm{~cm}$ dan panjang $40 \mathrm{~cm}$ dapat dibuat kreasi anyaman. Setelah diberikan penjelasan dan peragaan langkah-langkah membuat anyaman bentuk bintang semua peserta pelatihan langsung mempraktekkannya dengan mendapatkan bimbingan dari satgas dengan dibantu alumni dan mahasiswa PGSD.

\section{Hasil Fisik}

Hasil fisik berupa model-model anyaman yang dibuat dari kertas Asturo, yang dibuat oleh peserta pelatihan sebagai beriku: (1) hasil berlatih membuat anyaman model ikan yang dibuat dari kertas asturo ada dua macam yakni: model ikan 1 dengan ciri badan ikan memberi kesan segitiga, ada yang menyebut pesawat dan model ikan 2 bercirikan badan ikan menonjol (lebih memberikan kesan tiga dimensi). Contoh karya model Ikan 1 dan Ikan 2 yang dibuat oleh peserta pelatihan terlihat pada gambar 4. (2) hasil membuat anyaman model Pita yang dibentuk Pigura pada bidang Karton A3 terlihat pada gambar 5; (3) hasil berlatih membuat anyaman model burung terbang yang dibuat dari kertas asturo oleh peserta pelatihan dicontohkan pada gambar 6; (4) hasil berlatih membuat anyaman model Keranjang/Besek yang telah dibuat dari kertas asturo oleh setiap peserta dicontohkan pada gambar 7. Pada hasil anyaman model Keranjang atau Besek tersebut ada yang sudah bagus, rapi, cermat, namun sebagian masih belum rapi khususnya pada tahapan akhir penyelesain anyaman. Ujung-ujung kertas diakhir pembuatan anyaman keranjang seharusnya 
dilipat-diselipkan ke dalam atau keluar dengan ajeg, sambil dirapatkan dan kelebihan pita kertas digunting.
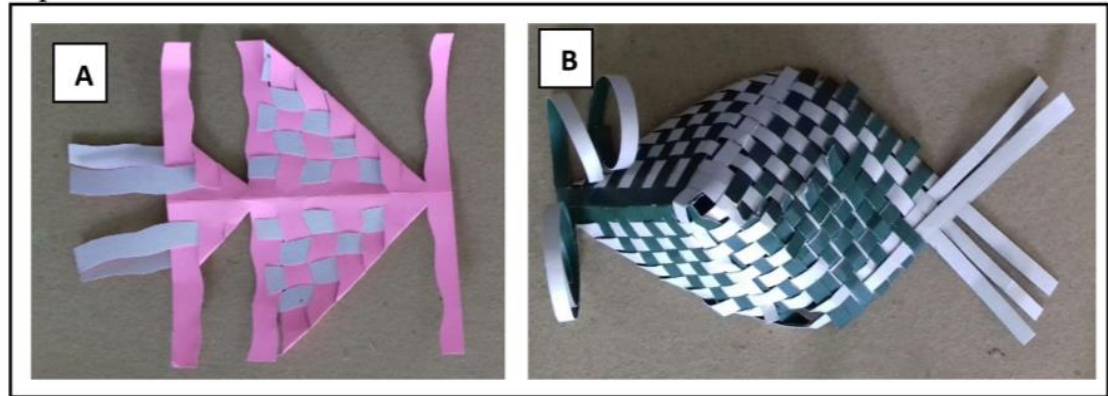

Gambar 4. Model ikan; A: model ikan 1 (pesawat), B: model ikan 2 (ikan koi)

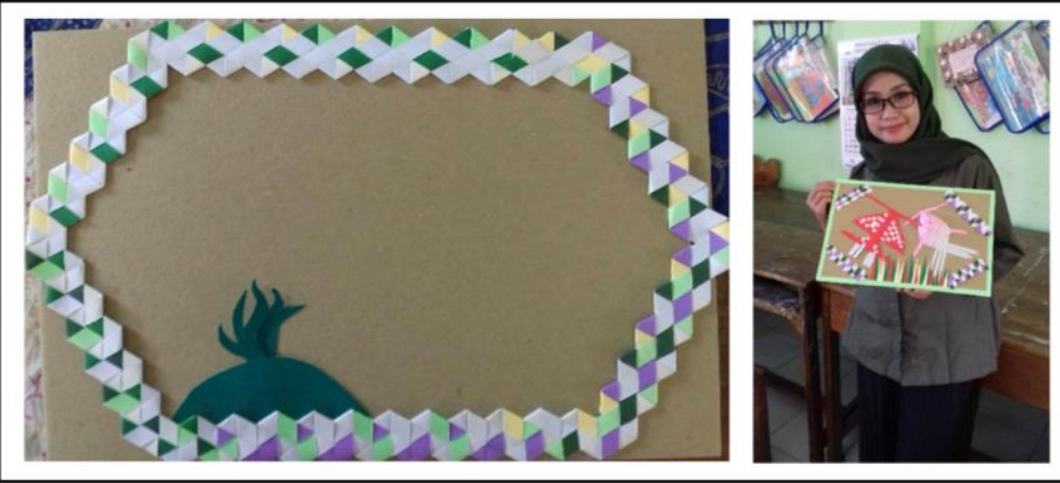

Gambar 5. Hasil membuat anyaman model Pita yang dibentuk Pigura

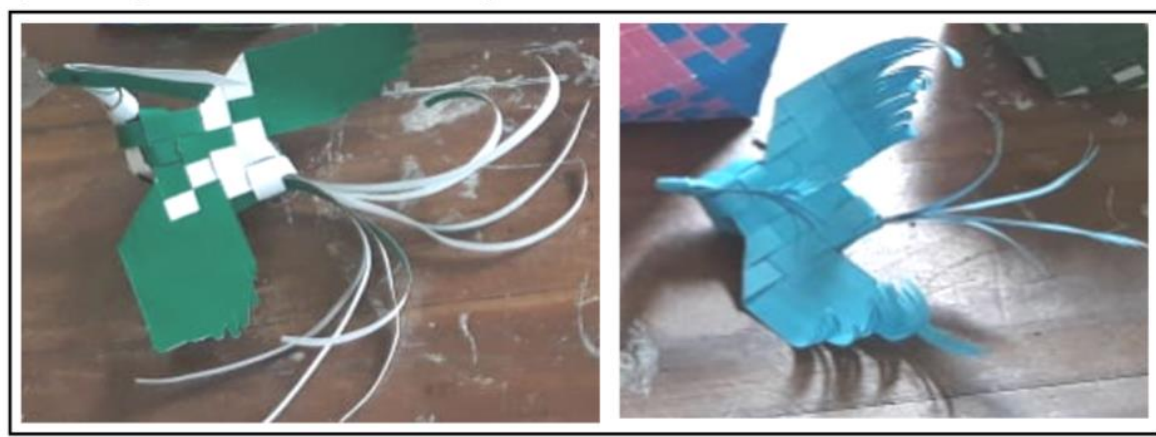

Gambar 6. Hasil berlatih membuat anyaman model burung terbang

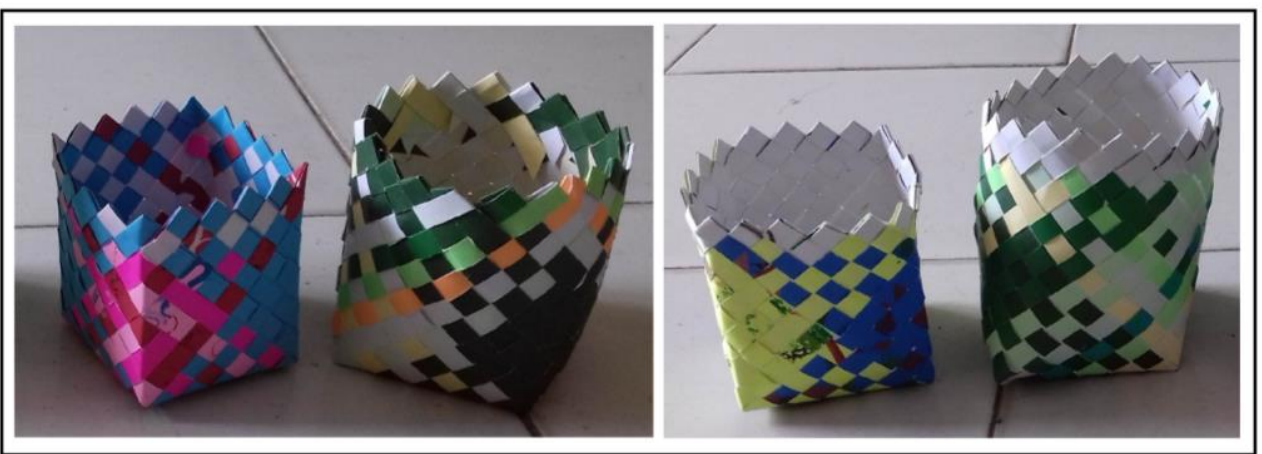

Gambar 7. Hasil berlatih membuat anyaman model Keranjang/Besek 


\section{Balikan peserta pelatihan SBdP bagi guru SD di Kecamatan Karangploso}

Berdasarkan balikan melalui instrumen yang diberikan kepada peseta pelatihan di akhir kegiatan diperoleh hasil baik mengenai kesesuaian materi, kejelasan sajian, kebermanfaatan, tingkat kemudahan dan kesulitan dipaparkan sebagai berikut. Dari keseluruhan peserta (19) yang mengisi balikan menyatakan bahwa: (1) materi pelatihan sangat sesuai (73.68\%), dan (26.31\%) menyatakan sesuai, (2) mengenai kejelasan sajian materi dan pemberian contoh cara pembuatan karya senirupa-prakarya menurut sebagian besar peserta pelatihan $(52.63 \%)$ sangat jelas, dan (43.36\%) peserta menyatakan jelas, (3) kebermanfaatan dari materi praktek berkarya senirupaprakarya yang telah dilatihkan sebagian besar peserta menyatakan sangat bermanfaat $(78.94 \%)$, dan bermanfaat (21.05\%). (4) Dilihat dari tingkat kesulitan-kemudahan dalam keseluruhan materi senirupa-prakarya yang dilatihkan peserta menyatakan mudah $(42.10 \%)$, dan cukup sulit dinyatakan oleh $(57.89 \%)$ peserta pelatihan.

Tingkat kesulitan dan kemudahan dari setiap materi praktek anyaman dan materi berkarya mencetak tinggi yang dinyatakan oleh peserta pelatihan dipaparkan sebagai berikut. Tingkat kesulitan dan kemudahan materi praktek kerajinan anyaman dari bahan kertas menunjukkan bahwa: (1) pada praktek anyaman model Ikan 1 sebagian besar (15) peserta pelatihan menyatakan sangat mudah $(47.36 \%)$, dan $52.63 \%$ menyatakan mudah. (2) Tingkat kesulitan-kemudahan dalam pembuatan anyaman model Ikan 2 dinyatakan oleh peserta pelatihan yaitu (57.89\%) mudah, (36.84\%) cukup sulit, dan ada seorang peserta (5.26\%) menyatakan sangat mudah. (3) Tingkat kesulitan-kemudahan dalam pembuatan anyaman model Pigura dinyatakan oleh sebagian besar peserta pelatihan (84.21\%) adalah cukup sulit, (5.26\%) menyatakan sangat sulit, dan (10.53\%) menyatakan mudah. (4) Tingkat kesulitan-kemudahan dalam pembuatan anyaman model Burung Terbang dinyatakan oleh peserta pelatihan (78.94\%) cukup sulit, dan $(21.05 \%)$ menyatakan mudah. (5) Tingkat kesulitan-kemudahan dalam pembuatan anyaman model Bintang dinyatakan oleh sebagian peserta pelatihan $(68.42 \%)$ yaitu cukup sulit, (5.26\%) menyatakan sangat sulit, dan (26.31\%) menyatakan mudah. (6) Tingkat kesulitan-kemudahan dalam pembuatan anyaman model Kotak dinyatakan oleh sebagian besar peserta pelatihan (73.69\%) cukup sulit, dan (26.31\%) menyatakan mudah.

Menurut peserta pelatihan yang masih merasakan adanya kesulitan dalam pembuatan setiap model atau bentuk kerajinan anyaman menyatakan sebagai berikut. Pertama, pada pembuatan anyaman model Ikan 1. Masih ada sedikit kesulitan yaitu ditahap awal menganyam silang membentuk badan pesawat. Kedua, pada pembuatan anyaman Model Ikan 2. kesulitannya yaitu kerapian dalam memotong, saat menyatukan bagian yang telah dianyam (langkah pertama), kesulitan dalam memotong kertas, kertas mudak sobek, kadang jumbuh langkah anyaman yang dibuat, melipat/menekuk dua sisi menganyamnya. Ketiga, pada pembuatan anyaman model Pigura. kesulitannya yaitu belokan langkah-langkah dan untuk membelokan langkah anyaman, batas belokan, bagian sudut anyaman, kertas mudah robek, menyimetriskan bentuk sampai tahapan menyambung ke dua ujung anyaman (anyaman langkah awal dengan anyaman langkah akhir). Keempat, pada pembuatan anyaman model Burung Terbang. kesulitannya yaitu badan, kepala, sayap, paruh, anyaman belakang, bentuk tubuh, menentukan bentuk leher, sering dompo dan kurang rapi hasil anyamannya. Kelima, pada pembuatan anyaman model Bintang. kesulitannya yaitu pembentukan bentuk binatang, menentukan belokan, membentuk pita, membentuk bagian atas, menentukan lekukan, dan membentuk ujung binatang. Keenam, pada pembuatan anyaman model Kotak. kesulitannya yaitu menganyam setiap dudut kotak sampai membentuk badan kotak/besek, kemudian melanjutkan menganyam ujunng/pita kertas, dan terakhir mengakiti lipatan kunci ke bagian dalam badan anyaman.

\section{SIMPULAN}

Pertama, kegiatan pengabdian kepada masyarakat berupa pelatihan senirupa-prakarya bagi guru-guru SD di gugus 1 Kecamatan Karangploso ini bersifat Dikmas (pendidikan masyarakat). Lingkup materi pelatihan berupa bimbingan keterampilan berkarya kreatif: (1) seni mencetak tinggi dengan menggunakan alat potongan kardus, sterefoam, dan (2) berkarya menganyam bentuk 
ikan model 1, ikan model 2, anyaman pita dibentuk pigura, burung terbang, bintang, dan anyaman keranjang/besek, serta anyaman dompet dengan menggunakan bahan kertas asturo. Dari kegiatan pelatihan senirupa-prakarya untuk meningkatkan kualitas pembelajaran senirupa bagi guru di SD di gugus 1 kecamatan Karangploso telah berhasil dengan baik.

Kedua, secara khusus, keberhasilan kegiatan ini meliputi: (a) guru SD peserta pelatihan telah dapat menjelaskan konsep pengembangan materi berkarya kreatif senirupa khususnya menganyam bahan kertas asturo dan mencetak tinggi bahan kardus, sterefoam, dan (b) guru SD peserta pelatihan telah terampil melakukan teknik mencetak tinggi, dan menganyam sesuai bahan yang digunakan dan kreasi yang dibuat, (c) guru SD peserta pelatihan telah mampu membuat karya anyaman bentuk ikan model 1, ikan model 2, anyaman pita, model anyaman burung terbang, anyaman bentuk bintang, dan anyaman kotak/besek, serta anyaman dompet.

Saran pelatihan dari peserta pelatihan yaitu sudah bagus, penambahan pelatihan, waktu pelatihan perlu ditambah dan berkelanjutan, pelatihan lebih dari 2 hari, lebih mendetail penjelasannya, pelatihan tidak pada bulan puasa, waktu terlalu cepat. Saran materi yaitu materi perlu ditambah, waktu pelatihan perlu ketelatenan dan kerapian, adanya penambahan pendamping, pakai pita daripada kertas, menggunakan kertas yang tidak robek, perlu dikembangkan dengan keterampilan yang lain dengan model yang variatif.

\section{DAFTAR RUJUKAN}

Karamil, C. (1999). Pendidikan Seni Rupa dan Kerajinan Tangan. Jakarta : Universitas Terbuka Pamadhi, H., Sukardi, E., \& Muis, A. (2008). Seni Keterampilan Anak. Jakarta: Penerbit UT.

Sumanto. (2005). Pengembangan Kreativitas Senirupa Anak TK. Jakarta: Dirjen Dikti.

Sumanto. (2006). Pengembangan Kreativitas Senirupa Anak Sekolah Dasar. Jakarta: Depdiknas Ditjen Dikti, Direktorat Ketenagaan.

Sumanto. (2006). Pengembangan Sumber Belajar Pendidikan Seni Rupa SD/MI. Jurnal Sekolah Dasar, 15(2).

Sumanto. (2011). Pendidikan Senirupa di Sekolah Dasar. Malang: FIP UM.

Sumaryadi, Ramanto, M., \& Zahri, W. (1992). Pendidikan Keterampilan . Jakarta : Dirjen Dikti Depdiknas 